\title{
Controls on nitrification in a water-limited ecosystem: experimental inhibition of ammonia-oxidising bacteria in the Patagonian steppe
}

\author{
Nancy I. López ${ }^{\mathrm{a}}$, Amy T. Austin ${ }^{\mathrm{b}}$, Osvaldo E. Sala ${ }^{\mathrm{b}}$, Beatriz S. Méndez ${ }^{\mathrm{a}, *}$ \\ ${ }^{a}$ Departamento de Química Biológica, Facultad de Ciencias Exactas y Naturales, Universidad de Buenos Aires, Ciudad Universitaria Pabellón 2, 1428 \\ Buenos Aires, Argentina \\ ${ }^{\mathrm{b}}$ Cátedra de Ecología-IFEVA, Facultad de Agronomía, Universidad de Buenos Aires and CONICET, Buenos Aires, Argentina
}

Received 17 April 2002; received in revised form 5 August 2003; accepted 13 August 2003

\begin{abstract}
We studied controls on nitrification in an undisturbed water-limited ecosystem by inhibiting autotrophic nitrifying bacteria in soils with varying levels of vegetative cover. The activity of nitrifying bacteria was disrupted using nitrapyrin, 2-chloro-6-(trichloromethyl)-pyridine, under field conditions in three microenvironments (underneath shrubs, next to grasses and in bare soil). Ammonia-oxidising bacteria were detected by PCR analysis of DNA in soils. The inhibition of nitrification changed the concentrations of $\mathrm{NO}_{3}^{-}$and $\mathrm{NH}_{4}^{+}$in the soil, while the microenvironment was most important in determining the response of bacteria to the inhibitor. Nitrapyrin application resulted in a significant $(p<0.05)$ reduction in soil $\mathrm{NO}_{3}^{-}$concentration $(39 \%)$ and a significant increase $(p<0.001)$ in soil $\mathrm{NH}_{4}^{+}$concentration $(41 \%)$. Untreated bare-soil microenvironments had the lowest concentrations of $\mathrm{NH}_{4}^{+}(1.57 \mu \mathrm{g} / \mathrm{g}$ of dry soil $)$ and $\mathrm{NO}_{3}^{-}(0.49 \mu \mathrm{g} / \mathrm{g}$ of dry soil $)$ when compared to the other microenvironments, and showed the highest impacts of nitrification inhibition. For example, $\mathrm{NH}_{4}^{+}$concentrations increased $288 \%$ and $\mathrm{NO}_{3}^{-}$concentrations decreased $60 \%$ in inhibited bare-soil microenvironments. In contrast, untreated microenvironments underneath shrubs had the highest levels of $\mathrm{NH}_{4}^{+}\left(10.01 \mu \mathrm{g} / \mathrm{g}\right.$ of dry soil) and $\mathrm{NO}_{3}^{-}(0.69 \mu \mathrm{g} / \mathrm{g}$ of dry soil), but showed no significant effects of inhibition of nitrification on soil nitrogen concentrations.
\end{abstract}

(C) 2003 Elsevier Ltd. All rights reserved.

Keywords: Ammonia-oxidising bacteria; Nitrapyrin; Ammonia monooxygenase gene (amoA); Nitrogen; Nitrification; Semi-arid ecosystems

\section{Introduction}

Chemolithotrophic ammonia oxidation is a key process in the nitrogen cycle because it is the main route of ammonia oxidation in soils in most terrestrial ecosystems. Ammonia, produced by decomposition of organic material (ammonification), is oxidized to nitrite by ammoniaoxidising bacteria in a two-step reaction. The first step is catalyzed by ammonia monooxygenase (AMO) and involves the oxidation of ammonia to hydroxylamine, which is subsequently oxidized to nitrite by hydroxylamine oxidoreductase (Paul and Clark, 1996). Finally, nitrite is oxidized to nitrate by nitrite-oxidising bacteria. Although environmental factors such as $\mathrm{pH}$ and substrate availability have been shown to affect the growth and survival of

\footnotetext{
* Corresponding author. Tel.: +54-11-4576-3334; fax: +54-11-45763342.

E-mail address: bea@qb.fcen.uba.ar (B.S. Méndez).
}

ammonia oxidizers in pure culture experiments (Gerards et al., 1998), the knowledge of factors controlling the functioning of ammonia-oxidising populations in natural ecosystems is scarce. Few studies have been done in situ with soils from natural ecosystems (Stark and Firestone, 1996).

Ecosystem processes in semi-arid ecosystems such as those located in the Patagonian region of Argentina, are primarily limited by water availability (Sala et al., 1989; Jobbágy and Sala, 2000). The Patagonian steppe is codominated by shrubs and grasses on a matrix of bare soil. Differences in litter quality and in microenvironmental factors such as temperature, soil water availability, and wind speed determine the existence of distinct microenvironments with contrasting functioning characteristics. In these microenvironments, water-nitrogen interactions may ultimately determine seasonal and annual productivity patterns. Our understanding of how ammonia oxidation activity impacts nitrogen availability in arid ecosystems in general, 
and in these Patagonian ecosystems in particular, remains largely unknown.

One approach to examine the importance of nitrification in soils has been the use of chemical inhibitors, which disrupt the first step of the nitrification reaction (conversion of ammonia to nitrite). These chemicals, such as nitrapyrin (N-Serve ${ }^{\circledR}$, 2-chloro-6-(trichloromethyl)-pyridine), were primarily developed for agricultural use. Nitrapyrin inhibits the AMO enzyme by acting as an alternative substrate (Goring, 1962; Iizumi et al., 1998), but does not appear to directly affect other microbially mediated processes of the nitrogen cycle (Sahrawat, 1989). Nitrapyrin has also been used in natural ecosystems to evaluate the importance of trace gas losses and nitrogen turnover (Schlesinger and Peterjohn, 1991; Bauhus et al., 1996; Ward et al., 1997).

The general objective of this study was to explore the importance of nitrification and its controls in water-limited ecosystems. In particular, we wanted to examine the roles of spatial heterogeneity and soil microbial populations in modulating nitrogen cycling in the Patagonian steppe, which we used as a model ecosystem. Our approach was to disrupt the activity of autotrophic nitrifying bacteria in microenvironments with different vegetation types, which result in contrasting biotic and abiotic characteristics, and examine the consequences of this disruption for nitrogen turnover. We evaluated the changes in soil biogeochemistry through measurements of inorganic nitrogen and monitored the presence of ammonia oxidising bacteria through PCR detection of the AMO coding gene (amoA) in soils from three microenvironments (under shrubs, grasses, and bare soil) characteristic of the semi-arid Patagonian steppe.

\section{Materials and methods}

\subsection{Study area}

The experimental site is part of the Río Mayo experimental station, which is located in the Argentinean province of Chubut $\left(45^{\circ} 41^{\prime} \mathrm{S}\right.$ and $\left.70^{\circ} 16^{\prime} \mathrm{W}\right)$. Long-term mean annual precipitation of the site is $152 \mathrm{~mm}$, and is strongly seasonal, with the majority of the precipitation falling in the winter months (May-August). Monthly temperature ranges from a maximum of $15^{\circ} \mathrm{C}$ in January and a minimum of $1{ }^{\circ} \mathrm{C}$ in July. Soils are coarse-textured aridisols, with high gravel content and low water-holding capacity (Valle, 1998). The vegetation is classified as semiarid steppe, with the dominant life forms of perennial tussock grasses and shrubs, which account for $>95 \%$ of the aboveground biomass of this community (Sala et al., 1989; Golluscio and Sala, 1993). Vegetative cover is discontinuous, with cover of $25 \%$ by grass species and $12 \%$ by shrub species (Fernández et al., 1991). Ten-year average net primary production of the site is $56 \mathrm{~g} \mathrm{~m}^{-2} \mathrm{yr}^{-1}$ (Jobbágy and Sala, 2000).

\subsection{Experimental design and analytical methods}

We selected 16 circular plots of $25 \mathrm{~m}^{2}$ that each had a Mulinum spinosum shrub of approximately $1 \mathrm{~m}$ in diameter in the center. Plots were randomly assigned to control and inhibition treatments. Thus, for all purposes of this study, we had eight independent replicates. We applied $15 \mathrm{ml}$ of emulsified N-serve $24 \mathrm{E}^{\circledR}$ (DowElanco) dissolved in $1.5 \mathrm{l}$ of water to the $25 \mathrm{~m}^{2}$ area. Because nitrapyrin volatilizes on contact with air, we applied the water solution $3 \mathrm{~cm}$ below the soil surface using a modified seeding machine. Additionally, we applied the solution under the shrub canopy and in the middle of grass tussocks using a hollow metal stake with plastic tubing to insure complete application over the entire area of the plot. The combination of the modified seeding machine, with very small distance between contiguous furrows, and the applications underneath the canopy of shrubs and grasses resulted in a uniform distribution of the inhibitor. Because there was some disturbance involved with the application of the chemical, we used the same methodology but applied only water in the control plots. We applied N-serve (or water) every 4 months for a two-year period; the soils analyzed for this experiment come from a sampling date of October 1999, 18 months after the initiation of the experiment, and two days after the application of nitrapyrin for this date.

Soil samples were taken from the $0-5 \mathrm{~cm}$ surface of the soil using a PVC tube of $5 \mathrm{~cm}$ diameter in three locations representative of the conditions in each plot: bare soil; close to grass tussocks; and below the central shrub. Thus, for each microenvironment/inhibition treatment, there were eight $(n=8)$ replicate samples. Immediately upon return from the field, a subsample was put into a sealed plastic bag and kept refrigerated $\left(4^{\circ} \mathrm{C}\right)$ until they were delivered for DNA extraction in Buenos Aires. In the field, a second subsample was taken for determination of inorganic nitrogen concentrations using a standard extraction of $2 \mathrm{~N}$ $\mathrm{KCl}$ (Robertson et al., 1999a). The extracts were analyzed for nitrate and ammonium using an Alpkem Flow IV ${ }^{\circledR}$ (O-I Corporation, College Station, TX, USA) autoanalyzer. Water content was determined gravimetrically on a subsample of soil taken from each location, and soil $\mathrm{pH}$ was evaluated using a solution of 2:1 soil slurry with distilled water and read with an electrometric $\mathrm{pH}$ meter (Robertson et al., 1999b). Soil concentrations of ammonium, nitrate, and nitrate/ammonium ratios, soil water, and $\mathrm{pH}$ were tested using a two-way ANOVA (alpha of 0.05 in all cases) using the program Statistica ${ }^{\circledR}$.

We extracted soil DNA with a soil DNA isolation kit (Mo Bio Laboratories, Inc.) using $0.5 \mathrm{~g}$ of soil. PCR amplification of the $a m o A$ gene was performed as previously described using two degenerate synthetic oligonucleotides, which were suitable for amplifying amoA gene of a wide range of ammonia-oxidising bacteria (Rotthauwe et al., 1997). As a positive control we used a $491 \mathrm{bp}$ fragment, previously cloned and sequenced in our 
laboratory (López and Méndez, 2000). The amplification bands were checked for the presence of the amoA gene by Southern blot experiments (Sambrook et al., 1989) using as a probe a synthetic biotinylated oligonucleotide designed on the basis of the most conserved region of the amoA gene inside of the amplification fragment (5' GCTTCCTGTATGTGCGTACC $3^{\prime}$ ).

\section{Results}

The nitrapyrin application in this Patagonian natural ecosystem resulted in a significant $(p<0.05)$ reduction of the nitrate concentration in the soil and an increase in the ammonium concentration (Fig. 1). For soil $\mathrm{NH}_{4}^{+}$, there were significant effects of the inhibition treatment, location, and their interaction (two-factor ANOVA, $p<0.001,0.01$, and 0.01 , respectively). Nitrate concentrations also varied significantly with inhibition, with less nitrate in the inhibited plots (two-way ANOVA, $p<0.05$ ), but there was no effect of microenvironment on nitrate values. There were differences in abiotic characteristics among the microenvironments, with significantly higher soil water content under the shrubs and higher $\mathrm{pH}$ in both the shrub and bare soil, but there was no effect of nitrification inhibition on these variables (Table 1). These microenvironment differences translated to changes in ammonium concentrations and the response to nitrification inhibition, as soil $\mathrm{NO}_{3}^{-} / \mathrm{NH}_{4}^{+}$ concentrations were quite different among microenvironments and treatments (Table 1, Fig. 1).

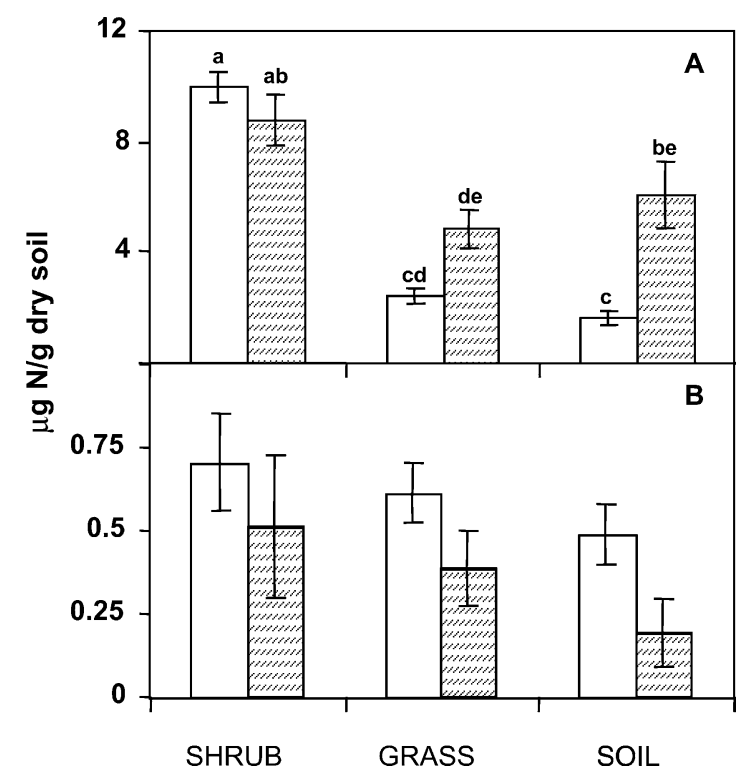

Fig. 1. Soil ammonium (A) and nitrate concentrations (B) in October 1999 in the Patagonian steppe. Bars are means at three sampling locations: under shrubs, next to grasses and bare soil. Control bars are open and hatched bars indicate inhibited plots. Different letters indicate significant differences at $p<0.01$ for ammonium. Nitrate concentrations showed significant differences with inhibition $(p<0.05)$, but there was no effect of microenvironment.
Table 1

Microenvironment characteristics in the Patagonian steppe

\begin{tabular}{llll}
\hline & Inhibitor applied & Soil water $\left(\% \mathrm{~g} \mathrm{H}_{2} \mathrm{O} / \mathrm{g}\right.$ dry soil $)$ & $\mathrm{pH}$ \\
\hline \multirow{2}{*}{ Shrub } & No & $3.84(0.22)^{\mathrm{b}}$ & $7.06(0.09)^{\mathrm{c}}$ \\
& Yes & $3.97(0.50)^{\mathrm{b}}$ & $7.14(0.14)^{\mathrm{c}}$ \\
\multirow{4}{*}{ Grass } & No & $2.87(0.35)^{\mathrm{a}}$ & $6.63(0.06)^{\mathrm{d}}$ \\
& Yes & $3.21(0.37)^{\mathrm{a}}$ & $6.63(0.11)^{\mathrm{d}}$ \\
\multirow{3}{*}{ Bare soil } & No & $2.43(0.34)^{\mathrm{a}}$ & $6.81(0.05)^{\mathrm{c}}$ \\
& Yes & $3.03(0.29)^{\mathrm{a}}$ & $6.94(0.09)^{\mathrm{c}}$ \\
\hline
\end{tabular}

Values of gravimetric soil water content and $\mathrm{pH}$ are means $(n=8, \pm \mathrm{se})$ for control and nitrification-inhibited plots. Letters indicate significant differences at $p<0.05$.

The shrub microenvironment had the highest soil $\mathrm{NH}_{4}^{+}$ concentrations of the three microenvironments (Fig. 1). Additionally, $\mathrm{NO}_{3}^{-} / \mathrm{NH}_{4}^{+}$ratios in the controls were lower than in any of the other microenvironments (Table 2). This relatively nitrogen-rich microenvironment showed no significant difference in soil $\mathrm{NH}_{4}^{+}$as a result of the inhibition treatments. Presence of shrubs may account for high soil $\mathrm{NH}_{4}^{+}$concentrations due to high inputs of organic matter in soil (Charley and West, 1975; Schlesinger et al., 1996). Shrub islands not only have high primary production (Soriano et al., 1994) but also trap a large fraction of windblown organic material, which may be produced in other microenvironments, all of which provide organic matter with carbon and nitrogen substrate for microbial growth and nitrogen mineralization.

The bare-soil microenvironment had the lowest ammonium concentrations and a high nitrate/ammonium ratio, associated with the absence of vegetative cover (Table 2 and Fig. 1). The inhibitor had a strong effect on the activity of the nitrifying bacteria with a sharp reduction in soil nitrate and an increase in ammonium concentrations (Fig. 1). It is important to highlight that nitrification inhibition resulted in a significant $(p<0.05)$ reduction in soil nitrate concentrations across the three microenvironments but the effect on nitrate concentrations was not significant for isolated microenvironments.

Table 2

Amplification of amoA gene and mean values of nitrate/ammonium ratios ( \pm se, $n=8)$ in three microenvironments of control and inhibition plots

\begin{tabular}{llll}
\hline Microenvironments & Inhibitor applied & $\mathrm{NO}_{3}^{-} / \mathrm{NH}_{4}^{+}$ & PCR \\
\hline \multirow{2}{*}{ Shrubs } & $\mathrm{No}$ & $0.07(0.01)^{\mathrm{b}}$ & $8 / 8$ \\
& Yes & $0.06(0.02)^{\mathrm{b}}$ & $8 / 8$ \\
Grass & No & $0.25(0.04)^{\mathrm{c}}$ & $4 / 8$ \\
& Yes & $0.09(0.03)^{\mathrm{b}}$ & $5 / 8$ \\
Bare soil & No & $0.41(0.11)^{\mathrm{a}}$ & $3 / 8$ \\
& Yes & $0.04(0.02)^{\mathrm{b}}$ & $2 / 8$ \\
\hline
\end{tabular}

Letters indicate significant differences for nitrate/ammonium ratios at $p<0.05$. PCR indicates number of positive amplification signals/number of analyzed samples as determined by agarose gel electrophoresis analysis. 
The grass microenvironment had soil concentrations of ammonium that were significantly $(p<0.05)$ lower than those in the shrub microenvironment but not significantly $(p>0.05)$ different from those in the bare-soil microenvironment (Fig. 1). The $\mathrm{NO}_{3}^{-} / \mathrm{NH}_{4}^{+}$ratios in this microenvironment were intermediate between those in the shrub and bare-soil microenvironments. The nitrification inhibition with nitrapyrin had a strong effect similar to that observed in the bare-soil microenvironment (Fig. 1).

Non-quantitative PCR experiments were conducted in order to monitor the presence of ammonia-oxidising bacteria. DNA extraction efficiency was similar for the three sampling points, with positive amplification signals found for soils from each of the three microenvironments (Table 2). The primers used to detect amoA gene resulted in only a single amplification product of the expected size. The detection limit in the amplification reaction, which was estimated by microplate technique (Rowe et al., 1977) ranged between 65 and 97 cells that probably contain 2-3 copies of amoA gene as demonstrated in several ammonia oxidizer studies (Mc Tavish et al., 1993; Norton et al., 1996). The identity of the PCR products was confirmed with randomly selected samples, which were subjected to Southern blot hybridization with an amoA gene probe (data not shown). The availability of $\mathrm{NH}_{4}^{+}$in the soil seems to affect the distribution of ammonia-oxidising populations in this water-limited ecosystem, as a larger number of amplification signals were detected in those areas with higher soil $\mathrm{NH}_{4}^{+}$concentration (Table 2). However, the PCR experiments performed in this work were non-quantitative and planned only to monitor the presence of ammoniaoxidising bacteria in this particular environment. Therefore, it cannot be concluded, at this point, that there is a direct link between the vegetation structure and the absolute size of the ammonia oxidising populations.

\section{Discussion}

In this paper, we have shown that nitrapyrin, an inhibitor of the action of the AMO enzyme, decreased $\mathrm{NO}_{3}^{-}$and increased $\mathrm{NH}_{4}^{+}$in a semi-arid native ecosystem with low soil nitrogen content and that there were large differences among microenvironments in the response of nitrifying bacteria to the inhibitor. This reduction in soil $\mathrm{NO}_{3}^{-}$suggests that autotrophic ammonia oxidation is the dominant path for nitrate production in this ecosystem. The magnitude of inhibition of nitrification with nitrapyrin was related to the soil $\mathrm{NH}_{4}^{+}$concentrations, in agreement with in vitro studies (Gerards et al., 1998). In vitro experiments using Nitrosomonas europaea cultures have shown that high ammonium concentration resulted in decreased inhibition activity of nitrapyrin (Vanelli and Hooper, 1992). The relatively high soil $\mathrm{NH}_{4}^{+}$under the shrub may have caused a reduction in the efficiency of the inhibition of autotrophic nitrification. Moreover, nitrapyrin is also known to bind to soil organic matter, which could further cause a reduction in the efficiency of inhibition, such that significant differences in soil $\mathrm{NH}_{4}^{+}$concentrations were not observed in the shrub microenvironment (Powell and Prosser, 1991).

The three microenvironments studied in this work possess soils with different vegetation characteristics (bare soil, grasses, and shrubs) and represent a range of physical and biotic characteristics for ammonia-oxidising bacteria. These differences translated to changes in nutrient dynamics and magnitude of nitrification inhibition in the three microenvironments. The high concentration of available substrate for nitrification underneath the shrub microenvironment results in a soil-vegetation interaction creating a 'hotspot' of nitrification potential and reduced effect of the inhibitor. These results indicate the importance of spatial heterogeneity, which may ultimately determine rates of carbon and nutrient turnover in this semi-arid steppe ecosystem.

\section{Acknowledgements}

This work was supported by the Inter-American Institute for Global Change Research (IAI) (CRN-012), an international research fellowship for ATA from the National Science Foundation, Fundación Antorchas, ANPCyT, and the University of Buenos Aires. Field support was provided by J. Vrsalovic, P. Flombaum, P. Roset, A. Beltran, A. Cesa, A. Milliones, S. Veron, L. Vivanco and laboratory assistance by M. Tagliazucchi, L. Vivanco, I. Montoya and M. Covalschi. S. Weicman provided technical assistance with PCR analysis. BSM, OES, ATA and NIL are career investigators from CONICET. We greatly appreciate the exhaustive comments made by the reviewers and the editor, which helped us to improve the manuscript presentation.

\section{References}

Bauhus, J., Meyer, A.C., Brumme, R., 1996. Effects of the inhibitors nitrapyrin and sodium chlorate on nitrification and $\mathrm{N}_{2} \mathrm{O}$ formation in an acid forest soil. Biology and Fertility of Soils 22, 318-325.

Charley, J., West, N., 1975. Plant-induced soil chemical patterns in some shrub-dominated semi-desert ecosystems in Utah. Journal of Ecology 63, 945-963

Fernández, R.J., Sala, O.E., Golluscio, R.A., 1991. Woody and herbaceous aboveground production of a Patagonian steppe. Journal of Range Management 44, 434-437.

Gerards, S., Duyts, H., Laanbroek, H.J., 1998. Ammonium induced inhibition of ammonium-starved Nitrosomonas europaea cells in soil and sand slurries. FEMS Microbiology Ecology 26, 269-280.

Golluscio, R.A., Sala, O.E., 1993. Plant functional types and ecological strategies in Patagonian forbs. Journal of Vegetation Science 4, $839-846$

Goring, C.A.I., 1962. Control of nitrification by 2-chloro-6-(trichloromethyl) pyridine. Soil Science 93, 211-218.

Iizumi, T., Misumoto, M., Nakamura, K., 1998. A bioluminiscence assay using Nitrosomonas euopaea for rapid and sensitive detection of 
nitrification inhibitors. Applied and Environmental Microbiology 64, 3656-3662.

Jobbágy, E.G., Sala, O.E., 2000. Controls on grass and shrub aboveground production in the Patagonian steppe. Ecological Applications 10, $541-549$.

López, N.I., Méndez, B.S., 2000. Uncultured ammonium-oxidizing bacterium UBA6-1 partial amoA gene for ammonia monooxygenase EMBL Nucleotide Sequence Database. Accession \#AJ277459.

McTavish, H., Fuchs, J.A., Hooper, A.B., 1993. Sequence of the gene coding for ammonia monooxygenase in Nitrosomonas europaea. Journal of Bacteriology 175, 2436-2444.

Norton, J.M., Low, J.M., Klotz, M.G., 1996. The gene encoding ammonia monooxygenase subunit A exists in three nearly identical copies in Nitrosospira sp. NpA V. FEMS Microbiology Letters 139, 181-188.

Paul, E.A., Clark, F.E., 1996. Soil Microbiology and Biochemistry, Academic Press, San Diego, CA.

Powell, J., Prosser, J.I., 1991. Protection of Nitrosomonas europaea colonizing clay minerals from inhibition by nitrapyrin. Journal of General Microbiology 137, 1923-1923.

Robertson, G.P., Wedin, D., Groffman, P.M., Blair, J.M., Holland, E.A., Nadelhoffer, K.J., Harris, D., 1999a. Soil carbon and nitrogen availability: nitrogen mineralization, nitrification, and soil respiration potentials. In: Robertson, G.P., Coleman, D.C., Bledsoe, C.S., Sollins, P. (Eds.), Standard Soil Methods in Long-Term Ecological Research, Oxford University Press, Oxford, pp. 258-271.

Robertson, G.P., Sollins, P., Ellis, B.G., Lajtha, K., 1999b. Exchangeable ions, $\mathrm{pH}$ and cation exchange capacity. In: Robertson, G.P., Coleman, D.C., Bledsoe, C.S., Sollins, P. (Eds.), Standard Soil Methods in LongTerm Ecological Research, Oxford University Press, Oxford, pp. $106-114$.

Rotthauwe, J.H., Witzel, K.P., Liesack, W., 1997. The ammonia monooxygenase structural gene amoA as a functional marker: molecular fine-scale analysis of natural ammonia-oxidizing populations. Applied and Environmental Microbiology 63, 4707-4712.

Rowe, R., Todd, R., Waide, J., 1977. Microtechnique for most-probablenumber analysis. Applied and Environmental Microbiology 33, $675-680$.

Sahrawat, K.L., 1989. Effects of nitrification inhibitors on nitrogen transformations, other than nitrification, in soils. Advances of Agronomy 42, 279-309.

Sala, O.E., Golluscio, R.A., Lauenroth, W.K., Soriano, A., 1989. Resource partitioning between shrubs and grasses in the Patagonian steppe. Oecologia 81, 501-505.

Sambrook, J., Fritsch, E.F., Maniatis, T., 1989. Molecular Cloning: A Laboratory Manual, Cold Spring Harbor, New York.

Schlesinger, W.H., Peterjohn, W.T., 1991. Processes controlling ammonia volatilization from Chihuahuan Desert soils. Soil Biology \& Biochemistry $23,637-642$

Schlesinger, W.H., Raikes, J.A., Hartley, A.E., Cross, A.F., 1996. On the spatial pattern of soil nutrients in desert ecosystems. Ecology 77, 364-374.

Soriano, A., Sala, O.E., Perelman, S.B., 1994. Patch structure and dynamics in a Patagonian arid steppe. Vegetatio 111, 127-135.

Stark, J.M., Firestone, M.K., 1996. Kinetic characteristics of ammoniumoxidizer communities in a California oak woodland-annual grassland. Soil Biology \& Biochemistry 28, 1307-1317.

Valle, H.F.D., 1998. Patagonian soils: a regional synthesis. Ecología Austral 8, 103-124.

Vanelli, T., Hooper, A.B., 1992. Oxidation of nitrapyrin to 6-chloropiconilic acid by the ammonia-oxidizing bacteria Nitrosomonas europea. Applied and Environmental Microbiology 58, 2321-2325.

Ward, B.B., Courtney, K.J., Langeheim, J.H., 1997. Inhibition of Nitrosomonas europaea by monoterpenes from coastal redwood (Sequoia sempervirens) in whole-cell studies. Journal of Chemical Ecology 23, 2583-2598. 